\title{
Assessing ecological quality of shallow lakes: Does knowledge of transparency suffice?
}

\author{
Edwin T.H.M. Peeters ${ }^{\mathrm{a}, *}$, Rob J.M. Franken ${ }^{\mathrm{a}}$, Erik Jeppesen ${ }^{\mathrm{b}, \mathrm{c}}$, Brian Moss ${ }^{\mathrm{d}}$, \\ Eloy Bécares ${ }^{\mathrm{e}}$, Lars-Anders Hansson ${ }^{\mathrm{f}}$, Susana Romo ${ }^{\mathrm{g}}$, Timo Kairesalo ${ }^{\mathrm{h}}$, \\ Elisabeth M. Gross ${ }^{\mathrm{i}}$, Ellen van Donk ${ }^{\mathrm{j}}$, Tiina Nõges ${ }^{\mathrm{k}}$, Kenneth Irvine, \\ Ryszard Kornijów $^{\mathrm{m}}$, Marten Scheffer ${ }^{\mathrm{a}}$
}

\author{
${ }^{a}$ Department of Environmental Sciences, Aquatic Ecology and Water Quality Management Group, \\ Wageningen University P.O. Box 8080, 6700 DD Wageningen, The Netherlands \\ ${ }^{\mathrm{b}}$ National Environmental Research Institute, Vejlsøvej 25, DK 8600 Silkeborg, Denmark \\ ${ }^{\mathrm{c}}$ Department of Plant Biology, Aarhus University, Ole Worms Allé 135, DK 8000 Aarhus C, Denmark \\ ${ }^{\mathrm{d}}$ School of Biological Sciences, University of Liverpool, P.O. Box 147, Liverpool L69 3BX, United Kingdom \\ ${ }^{\mathrm{e}}$ Instituto de Medio anbiente, La Serna 56, 24007, Leon, Spain \\ ${ }_{\mathrm{f}}^{\mathrm{f}}$ Department of Limnology, University of Lund, Lund, Sweden \\ ${ }^{\mathrm{g}}$ Àrea de Ecologïa, Facultad Biología, Edifico Investigación, Campus Burjasot, 46100 Burjasot, Valencia, Spain \\ ${ }^{\mathrm{h}}$ Department of Ecological and Environmental Sciences, University of Helsinki, Niemenkatu 79, FIN 15140 Lahti, Finland \\ ${ }^{\mathrm{i}}$ Fachbereich Biologie, Limnologisches Institut, Postfach M 659, University of Konstanz, 78547 Konstanz, Germany \\ ${ }^{\mathrm{j} N I O O} \mathrm{KNAW}$ Centre for Limnology, Rijksstraatweg 6, 3631 AC Nieuwersluis, The Netherlands \\ ${ }^{\mathrm{k}}$ Institute of Agricultural and Environmental Sciences, Centre for Limnology, Estonian Agricultural University, 61101 Rannu, \\ Tartu County, Estonia \\ ${ }^{1}$ Department of Zoology, School of Natural Sciences, Trinity College, Dublin 2, Ireland \\ ${ }^{\mathrm{m}}$ Department of Hydrobiology and Ichthyobiology, University of Agriculture in Lublin, Lublin 20 950, Poland
}

\begin{abstract}
The European Water Framework Directive (WFD) requires that all aquatic ecosystems in their member states should reach 'good' ecological quality by 2015. To assess ecological quality, the WFD requires the definition of reference conditions using biological, physical and chemical indicators and the assignment of each water body to one of five quality classes using these indicators. Elaborate assessment schemes using large sets of variables are now being developed. Here we address the question whether all this is really needed and what the simplest assessment approach would be for the case of shallow lakes. We explore the relationships between the quality class assigned to a lake by experts in shallow lake ecology and a rich set of biological, physical, and chemical data. Multinomial logistic regression analyses were carried out based on data from 86 shallow lakes throughout Europe that were sampled in 2000 and/or 2001. Ecological quality of shallow lakes judged by experts was strongly correlated to physical and chemical variables associated with light regime and nutrients and much less to biological variables.

Our regression model showed that ecological quality of this set of shallow lakes judged by experts could be predicted quite well from water transparency expressed as Secchi depth and that other variables did not contribute to it
\end{abstract}

\footnotetext{
${ }^{*}$ Corresponding author. Tel.: + 31317483898 ; fax: + 31317419000 .

E mail address: edwin.peeters@wur.nl (E.T.H.M. Peeters).
} 
significantly. According to the WFD, lakes should at least have a 'good' ecological quality. Quality judged by experts and predicted quality were similar for $78 \%$ of the lakes with respect to meeting this standard. As a cautionary note we stress that Secchi depth alone will be a less useful indicator if effects of stressors other than eutrophication (e.g. lake acidification and toxic pollution) are to be considered.

\section{Zusammenfassung}

Die Europäische Wasserrahmenrichtline (WRRL) fordert das Erreichen eines 'guten' ökologischen Zustands aller aquatischen Ökosysteme in den EU-Mitgliedsländern bis zum Jahr 2015. Die ökologische Qualität wird nach der WRRL über Referenzsysteme basierend auf biologischen, physikalischen und chemischen Indikatoren in fünf Qualitätsstufen eingeteilt. Hierzu werden derzeit basierend auf umfangreichen Datensätzen Bewertungsschemata entwickelt. In diesem Artikel stellen wir die Frage, ob dieses Vorgehen so notwendig ist, und welches der einfachste Ansatz zur Bewertung von Flachseen ist. Wir haben den Zusammenhang zwischen der durch Experten zugewiesenen Qualitätsklasse eines Sees und einem umfangreichen Datensatz mit biologischen, physikalischen und chemischen Daten untersucht. Anschließend wurden basierend auf dem Datensatz von 86 Flachseen in ganz Europa aus den Jahren 2000 und 2001 multinominale logistische Regressionsanalysen durchgeführt. Die Einschätzung der Qualität durch Experten korrelierte stark mit physikalischen und chemischen Parametern, welche Licht- und Nährstoffverfügbarkeit widerspiegeln, bezog sich aber kaum auf biologische Parameter. Unser Regressionsmodell zeigt, dass sich die Experten-gestützte Qualitätseinstufung bei diesem Datenset gut aus der Secchitiefe vorhersagen lässt, und dass andere Variablen kaum zu einer verbesserten Prognose führen. Seen müssen nach der WRRL mindestens einen „guten” ökologischen Zustand aufweisen. Die Expertenmeinung und die Qualitätsprognose anhand der Messdaten waren für 78\% der Seen deckungsgleich im Hinblick auf das Erreichen dieses Standards. Wir möchten aber darauf hinweisen, dass die Secchitiefe allein nicht ausreichend ist, wenn andere Einflüsse als Eutrophierung auf das Gewässer einwirken, wie z.B. Versauerung oder Belastung mit toxischen Substanzen.

Keywords: ECOFRAME; Eutrophication; Expert judgement; Lake management; Modelling; Multinomial logistic regression; Prediction; Restoration; Secchi depth; Water framework directive

\section{Introduction}

Research assessing the quality or 'health' of aquatic ecosystems has recently received much attention in Europe with the approval of the European Water Framework Directive (WFD; Directive 2000/60/EC of the European Parliament and of The Council of 23 October, 2000 establishing a framework for community action within the field of water policy). All aquatic ecosystems in the member states are required to obtain at least 'good' ecological quality by 2015 . Although five quality classes are defined (bad, poor, moderate, good and high), the means of assigning ecosystems to these categories are still open to debate. The only definitions in the Directive that are not circular in nature are that high quality has minimal human influence and that good quality is only slightly different from high quality. In Annex V, the WFD requires use of detailed biological, physical and chemical variables including information on composition, abundance and biomass of phytoplankton, phytobenthos, benthic invertebrate fauna, macrophytes and the composition and abundance of the fish community and the age structure of the fish populations.
The use of extensive lists of species and environmental variables is becoming more common in evaluating the quality of ecosystems (Parsons, Thoms, \& Norris, 2004; Reynoldson, Norris, Resh, Day, \& Rosenberg, 1997; Tonn et al., 2003). Although the collection of comprehensive and detailed information is useful for many purposes, it may be debated how detailed the information needs to be for assessing ecological quality. Moss et al. (2003) wrote: "It is the tragedy of our time, perhaps of all times, that we must set up expensive and elaborate measures to do what, with experience, and consensus within society as to its environmental goals, could be done much more easily."

Knowledge and experience of experts is a valuable source of information in ecological sciences such as conservation biology (Regan, Master, \& Hammerson, 2004), the development of reference lists (Richardson \& Healey, 1996), and bioassessment (Sullivan, Saunders, Tonnessen, Nash, \& Miller, 2005). Generally, experts use a combination of logic, common sense, skill, experience and judgement, to generate a final assessment that is intended to be timely, relevant, and meaningful (Rush \& Roy, 2001). Although expert judgement plays an important role in the ecological assessment of aquatic 
systems, there has been little formal justification as to whether expert knowledge has any relationship with measured environmental and/or biological variables.

The objectives of our study are to analyze whether quality judged by experts coincides with differences in abiotic and biotic circumstances and to find a simple way of predicting quality of lakes. We explore empirical relationships between quality classes assigned to lakes by known experts using field observations and a rich set of biological, physical and chemical data. Our aim is to find a simple model predicting the outcome of highquality expert judgement. For this purpose we used expert judgements and data from 86 shallow lakes in 10 European countries, which were sampled in 2000 and/or 2001 in a pan-European study (ECOFRAME). The aim of ECOFRAME was to develop an assessment system for the ecological quality of shallow lakes (Moss et al., 2003).

\section{Methods}

\section{Study sites}

At least six different shallow lakes were selected and sampled in 2000 and/or in 2001 in each of the 10 European countries that participated in the ECOFRAME project. Mean depth in all lakes was less than $3 \mathrm{~m}$ and the maximum depth was $6 \mathrm{~m}$. The lakes were chosen to cover a wide range of geographical regions and physical and chemical conditions. All lakes were natural in origin or naturalized if ultimately manmade, and none were 'heavily modified waters' as outlined in the WFD. Within the ECOFRAME project, all experts were trained biologists with at least several years of field experience in shallow lake ecology. In one project meeting prior to the sampling it was decided that each participating country should select at least six lakes covering the range from high to poor quality as defined by their own ideas. The experts assessed the ecological quality of the lakes based on their own previous experiences taking into account all kinds of deterioration. The finally selected lakes differed in their ecological

Table 1. Number of lakes per ecological quality class judged by experts

\begin{tabular}{lc}
\hline Presumed WFD quality class & Number of lakes \\
\hline Bad & 6 \\
Poor & 18 \\
Moderate & 26 \\
Good & 23 \\
High & 13 \\
\hline
\end{tabular}

Note that in our analyses the quality classes Bad and Poor were pooled. quality as judged by these experts (Table 1). Detailed information on the selected lakes is given by Moss et al. (2003).

\section{Collected data}

The selected lakes were sampled at least twice for chemical and physical properties in the period JulySeptember in 2000 and/or 2001. A total of 65 lakes were sampled in 2000 and 66 in 2001. In total, 86 different lakes had been sampled, 45 of which were sampled in both years. Biological data included indices related to macrophytes, phytoplankton, zooplankton, macroinvertebrates, and fish (Moss et al., 2003). Many abiotic variables were measured in both years, but the number of biotic variables measured was considerably reduced in 2001 (see Appendix A: Table 1). However, information on most of the abiotic variables was obtained in both years.

Summer averages were calculated for the abiotic variables and prior to the statistical analyses, variables with continuous data were log transformed. Since the number of lakes with a likely bad quality class was rather low (Table 1), these were combined with lakes assessed as having poor quality, resulting in four different quality classes. All data on fish were omitted, because in some member states no fish data were collected as the proposed method of sampling was forbidden.

\section{Data analyses}

Analyses of Variance (ANOVA) were performed with a variable describing the quality class judged by experts as explanatory variable and the other variables as dependent ones. Analyses were performed for both years separately to reveal which abiotic variables were of interest and to analyze which biological components showed a correlation with the ecological quality.

Multinomial logistic regression is a generalized linear model (GLM). It is an extension of the binomial logistic regression and may be applied when the response variable has more than two categories. GLM allows various distributions for the response and error terms in the model (Hosmer \& Lemeshow, 1989; McCullagh \& Nelder, 1989). Multinomial logistic models are multiequation models and a response variable with $k$ categories will generate $k-1$ equations with each equation being a binary logistic regression comparing a group with the reference group. Therefore, the multinomial logistic regression model describes the probability of occurrence of each category as a function of the explanatory variables. The maximum likelihood principle is used to estimate the values for the parameters in the equations and the likelihood ratio 
test is applied to assess the significance of the estimated parameters by comparing the predictive value of models including the estimated parameters with those not including them. A parameter is excluded if its removal does not lead to a decrease in the power of the model (Trexler \& Travis, 1993). Furthermore, the reduction in deviance is used to assess the contribution of a model to the explanation of the variance in the data points. The deviance of a model with only a constant term is equivalent to apportioning all of the variation to a random (error) component and is analogous to the total sum of squares in normal linear regression.

Multinomial logistic regressions were applied with a variable describing the quality class judged by experts as a dependent variable. Preliminary logistic regressions were performed for both years separately with all available abiotic and biotic data. The results demonstrated that some abiotic variables contributed significantly (Secchi depth plus TP in 2000 and chlorophyll- $a$ in 2001) and that all biological variables were excluded from the regression model. Therefore, the final multinomial logistic regressions were performed with summer averaged values of Secchi depth, TP and chlorophyll- $a$ and multiple analyses were applied in order to determine the minimal set of variables required for predicting the probability of a certain ecological quality. Cross-validation can be an efficient tool to evaluate the predictive ability of a regression model (Van Houwelingen \& Le Cessie, 1990) and in this study the leave-one-out cross-validation was applied. In this procedure, a single observation is used as the validation data and the model is built with all the other data. This is repeated such that each observation is used once as

Table 2. Results of significant ANOVAs for 2000 and 2001

\begin{tabular}{|c|c|c|c|c|c|c|c|}
\hline \multirow[t]{2}{*}{ Variable } & \multirow[t]{2}{*}{$F$} & \multirow[t]{2}{*}{ d.f. } & \multirow[t]{2}{*}{$P$} & \multicolumn{4}{|c|}{ Post hoc groups } \\
\hline & & & & $\mathrm{Bad} /$ poor & Moderate & Good & High \\
\hline \multicolumn{8}{|l|}{2000} \\
\hline \multicolumn{8}{|l|}{ Abiotic } \\
\hline Temp & 3.142 & 3.62 & 0.031 & $\mathrm{~B}$ & B & $\mathrm{B}$ & A \\
\hline $\mathrm{pH}$ & 2.713 & 3.62 & 0.050 & $\mathrm{~B}$ & $\mathrm{AB}$ & $\mathrm{AB}$ & A \\
\hline $\mathrm{TP}$ & 9.216 & 3.62 & 0.000 & $\mathrm{C}$ & B & $\mathrm{B}$ & A \\
\hline TN:TP ratio & 9.598 & 3.56 & 0.000 & $\mathrm{~B}$ & $\mathrm{~B}$ & $\mathrm{AB}$ & A \\
\hline Chlorophyll $a$ & 7.205 & 3.62 & 0.000 & $\mathrm{~B}$ & $\mathrm{~B}$ & $\mathrm{AB}$ & A \\
\hline Secchi depth & 38.455 & 3.62 & 0.000 & $\mathrm{C}$ & $\mathrm{B}$ & $\mathrm{B}$ & A \\
\hline Suspended solids & 7.403 & 3.62 & 0.000 & $\mathrm{~B}$ & B & $\mathrm{B}$ & A \\
\hline Maximum depth & 6.825 & 3.62 & 0.000 & $\mathrm{~B}$ & $\mathrm{AB}$ & $\mathrm{AB}$ & A \\
\hline \multicolumn{8}{|l|}{ Phytoplankton } \\
\hline Biovolume chlorophyta & 5.185 & 3.62 & 0.003 & B & A & $\mathrm{AB}$ & A \\
\hline Biovolume cryptophyta & 5.192 & 3.62 & 0.003 & $\mathrm{C}$ & $\mathrm{BC}$ & $\mathrm{B}$ & A \\
\hline$\%$ Biovolume cyanophyta & 3.889 & 3.62 & 0.013 & $\mathrm{~B}$ & $\mathrm{AB}$ & $\mathrm{AB}$ & A \\
\hline$\%$ Biovolume filam. Cyanophyta & 4.476 & 3.62 & 0.007 & A & A & A & A \\
\hline$\%$ Biovolume chlorophyta & 5.169 & 3.62 & 0.002 & A & A & A & A \\
\hline \% Biovolume chrysophyta & 3.569 & 3.62 & 0.019 & A & A & A & A \\
\hline \multicolumn{8}{|l|}{ Macrophytes } \\
\hline$\%$ Native plant species & 3.993 & 3.62 & 0.012 & B & A & A & A \\
\hline $\begin{array}{l}\text { No. submerged + floating plants } \\
\text { Maximum percentage volume }\end{array}$ & 4.320 & 3.62 & 0.008 & A & A & A & A \\
\hline Infested (PVI) submerged & 2.808 & 3.62 & 0.047 & $\mathrm{~B}$ & $\mathrm{AB}$ & A & $\mathrm{AB}$ \\
\hline \multicolumn{8}{|l|}{ Zooplankton } \\
\hline Cladocera $<0.4 \mathrm{~mm}$ & 2.832 & 3.62 & 0.045 & A & A & A & A \\
\hline \multicolumn{8}{|l|}{2001} \\
\hline \multicolumn{8}{|l|}{ Abiotic } \\
\hline $\mathrm{pH}$ & 5.023 & 3.63 & 0.004 & $\mathrm{~B}$ & $\mathrm{AB}$ & A & A \\
\hline $\mathrm{TP}$ & 9.754 & 3.63 & 0.000 & $\mathrm{C}$ & $\mathrm{BC}$ & $\mathrm{AB}$ & A \\
\hline Chlorophyll $a$ & 11.943 & 3.63 & 0.000 & $\mathrm{C}$ & B & $\mathrm{AB}$ & A \\
\hline Secchi depth & 23.604 & 3.63 & 0.000 & $\mathrm{C}$ & B & $\mathrm{B}$ & A \\
\hline \multicolumn{8}{|l|}{ Macrophytes } \\
\hline Abundance & 7.773 & 3.63 & 0.000 & B & $\mathrm{AB}$ & A & A \\
\hline
\end{tabular}

$F=$ test statistic, d.f. $=$ degree of freedom, and $P=$ significance. Quality classes with the same letter belong to the same homogeneous group obtained from a Tukey's post hoc test and differ from quality classes with a different letter. 
the validation data. All analyses were performed with the software program SPSS, version 10.1.

\section{Results}

The ANOVA results show that eight environmental and 10 biological variables contributed significantly to explaining differences between the quality classes judged by experts in 2000 and four environmental and one biological variables in 2001 (Table 2). Among the abiotic variables, especially variables related to the light regime (Secchi transparency, chlorophyll- $a$, suspended solids) and nutrients (total $\mathrm{P}, \mathrm{N}: \mathrm{P}$ ratio) were important. Tukey's post hoc tests showed that three homogeneous subsets existed for the environmental variables total phosphorus, Secchi transparency and chlorophyll- $a$ (in 2001) and two homogeneous subsets for the other environmental variables.

No soft- and hard-bottom macroinvertebrate indices had a significant relationship with the ecological quality judged by experts in 2000, and the same was true for epiphytic macroinvertebrate indices in 2000 and 2001. ANOVA showed that several biological variables had a significant contribution (Table 2) with biovolume of Chlorophyta, Cryptophyta, and Cyanophyta, percentage of native plant species, percentage-volume infested (PVI) with submerged plants, and in 2001, the abundance of plants, being the most important ones. Although significant, Tukey's post hoc test did not reveal homogeneous subsets for percentage biovolume of filamentous Cyanophyta, Chlorophyta and Chrysophyta, number of submerged and floating leaved plants and Cladocera $<4 \mathrm{~mm}$.

The reduction in deviance differed between the three variables when analyzed separately, with Secchi depth resulting in the highest reduction $(33.2 \%)$, followed by chlorophyll- $a(25.6 \%)$ and total phosphorus $(23.7 \%)$. Since logarithmically transformed Secchi depth data resulted in a lower reduction in deviance and in a lower percentage of well-predicted lake quality, untransformed Secchi depth data were used to build the model. Using the model with Secchi depth (see Appendix A model description) and adding the other two variables step-by-step showed that the additional variables had no significant additional effect. Obviously this is largely due to the high correlation between, e.g., Secchi depth and total phosphorus. Fig. 1, showing the probability of occurrence of a certain ecological quality class as a function of Secchi depth, clearly demonstrates that, as expected, higher ecological quality classes are only obtained for higher values of Secchi depth. The results of the leave-one-out cross-validation show that in $56 \%$ of the lakes the predicted quality class is equal to the quality class judged by experts (Table 3 ). Furthermore, the predicted value was higher in $16 \%$ of the lakes and

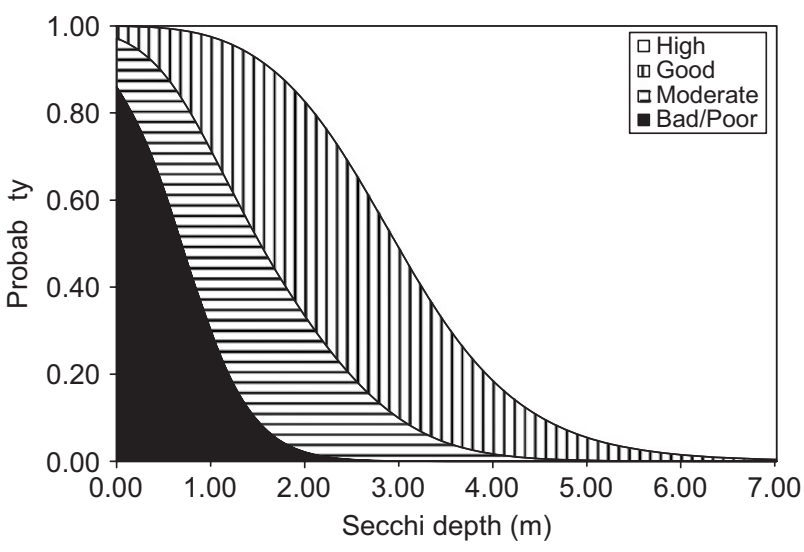

Fig. 1. Probability of occurrence of the ecological quality classes Bad/Poor, Moderate, Good, and High as a function of Secchi depth as obtained by multinomial logistic regression.

Table 3. The number of lakes per country for which the quality class predicted by the regression model is higher, equal or lower than the quality judged by experts

\begin{tabular}{|c|c|c|c|c|c|c|}
\hline \multirow[t]{3}{*}{ Country } & \multicolumn{6}{|c|}{$\begin{array}{l}\text { Predicted quality in comparison to quality } \\
\text { judged by experts }\end{array}$} \\
\hline & \multicolumn{3}{|c|}{ Using 4 classes } & \multicolumn{3}{|c|}{ Using 2 classes } \\
\hline & Higher & Equal & Lower & Higher & Equal & Lower \\
\hline Denmark & & 3 & 3 & & 6 & \\
\hline Estonia & 2 & 4 & 3 & 1 & 5 & 3 \\
\hline Finland & 2 & 6 & 1 & & 6 & \\
\hline Germany & & 6 & 2 & 1 & 7 & 1 \\
\hline Ireland & 4 & 3 & & 2 & 7 & \\
\hline Poland & 1 & 1 & 4 & & 4 & 2 \\
\hline Spain & & 12 & 6 & & 15 & 3 \\
\hline Sweden & & 6 & 1 & & 6 & 1 \\
\hline The Netherlands & 2 & 3 & 1 & 2 & 4 & \\
\hline United Kingdom & 3 & 4 & 3 & & 7 & 3 \\
\hline Total & 14 & 48 & 24 & 6 & 67 & 13 \\
\hline Percentage & 16.3 & 55.8 & 27.9 & 7 & 77.9 & 15.1 \\
\hline
\end{tabular}

Results are obtained from a leave one out cross validation using the four quality classes (bad/poor, moderate, good and high) and using the criterion of meeting the WFD standard (at least good quality).

in $28 \%$ the predicted quality was lower than the quality assessed by experts. The similarity between the predicted quality and the quality judged by experts was particularly high for Finland and Sweden. If the results of the leave-one-out cross-validation are used to analyze the number of lakes that meet the WFD criterion (at least good quality) it appeared that in $78 \%$ of the cases the predicted and quality judged by experts is similar (Table 3). In $15 \%$ of the lakes the predicted quality is lower than the quality assigned by experts and in only $7 \%$ the predicted quality was higher. This means that from the lakes that were classified as bad to moderate according to the experts (50, see Table 1 ) only $12 \%$ (6) 
had a higher quality according to the regression model. Furthermore, approximately $30 \%$ of the lakes with a good/high quality judged by the experts (36, see Table 1) had a lower quality according to the model.

Differences in predictions for the quality classes judged by experts 'high' and 'bad/poor' were rather small, whereas higher deviations were observed for the quality classes 'moderate' and 'good' quality as judged by the experts.

\section{Discussion}

Our analyses showed a clear relationship between ecological quality of shallow lakes judged by experts and a number of physical, chemical and biological variables. From the physical and chemical variables, those related to light regime and nutrients were most important. Differences among the ecological quality classes were most prominent for total phosphorus and Secchi transparency, with three significantly distinct subsets. Our analyses showed that variables with significant differences between the classes are linked with eutrophication and, therefore, it seems that the main quality gradient judged by the experts was the level of eutrophication despite the fact that subjective components will play a role (Boesten, 2000; Van Steen, 1992). However, it is not surprising that expert judgement is focussed on eutrophication as this is probably the major threat driving such lakes from a state of clear water and rich biodiversity to an impoverished situation with turbid water, cyanobacterial blooms and overall lower species numbers (Bootsma, Barendregt, \& Van Alphen, 1999; Jeppesen, Jensen, Søndergaard, Lauridsen, \& Landkildehus, 2000; Moss, 1988; Scheffer, 1998).

Most biological variables did not show significant relationships with quality. This result does not indicate that eutrophication in shallow lakes really has no effect on these groups, but merely that their response to eutrophication does not correspond with the quality classes defined or that it is too subtle to be readily detectable without extensive sampling. Furthermore, the identification level in the present study for phytoplankton, zooplankton, and invertebrates was not species but family and/or order level. According to De Eyto et al. (2003) the relationship between Chydoridae from the lakes sampled in 2000 and lake ecological quality was more apparent at species than at community level. However, other studies (Marchant, 2002) have demonstrated that identification to species level is not always necessary for the assessment of ecological quality. For example, the widely used biological monitoring working party (BMWP) score system for macroinvertebrates (e.g. Metcalfe, 1989) uses family and not species level.

Our regression analyses together with the crossvalidation showed that quality classes judged by experts can be well predicted from Secchi depth with a multinomial logistic regression model. At first, it may seem remarkable that expert judgement of complex ecosystems like shallow lakes may be mimicked by a single physical variable. This may partly be related to the gradients present or lacking in the dataset. An eutrophication gradient was clearly available in our database, but, for example, data on metals were lacking in our dataset. It has been demonstrated that severe metal and organic pollution may also lead to high transparency in the water because copper sulfate and herbicides are toxic to phytoplankton (e.g. Duvall, Anderson, \& Goldman, 2001; Hanson \& Stefan, 1984), while other pollutants may negatively affect fish stock and zooplankton with cascading effects on water clarity (Scheffer, Hosper, Meijer, Moss, \& Jeppesen, 1993). Acidification may also lead to enhanced clarity because the phosphorus concentrations are more tightly bound to inorganic substances (e.g Kopacek et al., 2004) and to fish kill, either because of reduced $\mathrm{pH}$ or release of toxic substances (e.g. Reckhow, Black, \& Stockton, 1987), which may cascade to water clarity. A third aspect is related to the length of the gradient present in our dataset. For example, excessively hypertrophic lakes were rare in our database. Such lakes may become clear because of fish kills due to low oxygen concentrations (high oxygen consumption) or high $\mathrm{pH}$ (Beklioglu, Carvalho, \& Moss, 1999; Jeppesen et al., 1998). Therefore, additional knowledge of total phosphorus and perhaps fish abundance would be needed to avoid misclassification of such systems (Søndergaard, Jeppesen, Jensen, \& Amsinck, 2005). Obviously, we cannot say how 'good' the judgement of quality by our model really is because it is difficult to evaluate how appropriate the expert judgement of the quality of the lakes is. Although approximately $45 \%$ of the lakes are misclassified when taking four quality classes into account and $20 \%$ in case of two classes (meeting the WFD standard or not), this will at least partly be related to some level of inconsistency or 'error' in expert judgement (Boesten, 2000; Van Steen, 1992). Our logistic regression model seems to be conservative in the sense that when there is a mismatch between the prediction and the expert judgement in most cases the predicted quality is lower. In our approach we mainly rely on the statistical significance testing of the variables, an objective tool for evaluating scientific hypotheses testing. However, the use of statistical significance testing as the best guideline for developing predictive models is still under debate (e.g. Harrell, 2001; Schmidt, 1996), and using other criteria may lead to improved results (e.g. Moons, Donders, Steyerberg, \& Harrell, 2004) but no standard alternative procedure is yet available. However, our approach demonstrates that, for a quick inventory, the use of a simple model based merely on Secchi depth may serve as a good measure for 
lake eutrophication especially in combination with additional knowledge of nutrient status and some biotic characteristics. Although, these measures might diagnose whether a lake deviates from a good or high quality, they do not provide information on possible causes and little information on how to manage and restore them (Moss, 1987). The theory of alternative stable states in shallow lakes by Scheffer et al. (1993) demonstrates that the degradation of a shallow lake associated often with nutrient enrichment may follow a different nutrient trajectory from the restoration of such a system. To manage and restore disturbed lakes, detailed knowledge at the ecosystem level is necessary.

Our results (Table 2) indicate that it will be difficult to discriminate between good and moderate state of shallow lakes using Secchi depth as the single measure of ecological state. This may indicate that experts typically can separate the very good from the very poor quality, whereas they err more often between good and moderate quality. This is unfortunate as a shift to at least a good state is required to fulfill the WFD and we can expect that efforts will have to be taken by member states to shift lakes from a moderate to a good ecological state. A more comprehensive scheme including more environmental and biological variables is therefore needed to identify if such a shift has occurred (see Moss et al., 2003; Søndergaard et al., 2005).

In conclusion, ecological quality of shallow lakes judged by experts coincides with changes in a number of abiotic and a limited number of biological variables. Multinomial logistic regressions showed that Secchi depth is the variable that best matches the quality judged by experts. Our minimal model may serve as a barometer for ecological quality of shallow lakes and seems conservative since most misclassified lakes had a lower predicted quality than that assigned by the experts. However, the model does not provide information on possible causes, nor on measures that should be taken to manage and restore disturbed shallow lake ecosystems. Further, it will be difficult to detect from Secchi depth alone, if a lake has shifted from a moderate to a good ecological state according to the WFD.

Based on the results of our analyses we propose the following procedure to make an inventory of the ecological quality of shallow lakes in a certain region. In a first step, it will be sufficient to let experts give a rough categorization of all lakes in the region taking into account factors like obvious sources of pollution and lake age supported by measuring Secchi depth in the period July-September. They will with high probability be able to separate lakes for which no management plan is needed since they can distinguish lakes with good and high ecological quality from lakes with low quality. This first step is a cheap way to reduce the number of lakes that require further attention. In a second step, additional biological, physical and chemical measurements are needed only for those lakes with a low quality to develop a sound management plan using the approach described by Moss et al. (2003).

\section{Acknowledgements}

The study was partially financed by the European Community (ECOFRAME EVK1-CT-1999-00039).

In addition to the authors, the following members of the ECOFRAME group contributed to the discussions and workshops which enabled the collection of data and the writing of this paper: Cristina Alvarez, Wouter van den Bund, S.E. Collings, Elvira de Eyto, Tõnu Feldmann, Camino Fernández-Aláez, Margarita Fernández-Aláez, Loles Boronat, Slavek Cerbin, Franscisco García-Criado, Mikael Gyllström, Ain Jãrvalt, JensPeder Jensen, Teet Krause, Helen Künnap, Alo Laas, Evi Lill, Bogdan Lorens, Helen Luup, Maria Rosa Miracle, Peeter Nõges, Mirva Nykänen, Ingmar Ott, Wojciech Peczula, Geoff Phillips, Victoria Russell, Jaana Salujõe, Klaas Siewertsen, Halina Smal, Debbie Stephen Claudia Tesch, Henn Timm, Lea Tuvikene, Ilmar Tõnno, Taavi Virro, Eduardo Vicente, and David Wilson. The authors thank Asger R. Pedersen for his valuable comments and contribution on the statistical analyses.

\section{Appendix A. Supplementary materials}

Supplementary data associated with this article can be found in the online version at doi:10.1016/j.baae. 2007.12.009.

\section{References}

Beklioglu, M., Carvalho, L., \& Moss, B. (1999). Pid recovery of a shallow hypertrophic lake following sewage effluent diversion: Lack of chemical resilience. Hydrobiologia, 412, 515.

Boesten, J. J. T. I. (2000). Deller subjectivity in estimating pesticide parameters for leaching models using the same laboratory data set. Agricultural Water Management, 44, 389409.

Bootsma, M. C., Barendregt, A., \& Van Alphen, J. C. A. (1999). Effectiveness of reducing external nutrient load entering a eutrophicated shallow lake ecosystem in the Naardermeer nature reserve, the Netherlands. Biological Conservation, 90, 193201.

De Eyto, E., Irvine, K., García Criado, F., Gyllström, M., Jeppesen, E., Kornijow, R., et al. (2003). The distribution of chydorids (Branchiopoda, Anomopoda) in European shallow lakes and its application to ecological quality monitoring. Archiv fur Hydrobiologie, 156, 181202.

Duvall, R. J., Anderson, L. W. J., \& Goldman, C. R. (2001). Pond enclosure evaluations of microbial products and 
chemical algicides used in lake management. Journal of Aquatic Plant Management, 39, 99106.

Hanson, M. J., \& Stefan, H. G. (1984). Side effects of 58 years of copper sulfate treatment of the Fairmont Lakes, Minnesota. Water Resources Bulletin, 20, 889900.

Harrell, F. E., Jr. (2001). Regression modeling strategies. With applications to linear models, logistic regression, and survival analysis. New York: Springer.

Hosmer, D. W., \& Lemeshow, S. (1989). Applied logistic regression. New York: Wiley.

Jeppesen, E., Søndergaard, M., Jensen, J. P., Mortensen, E., Hansen, A. M., Jorgensen, T., et al. (1998). Cascading trophic interactions from fish to bacteria and nutrients after reduced sewage loading: An 18 year study of a shallow hypertrophic lake. Ecosystems, 1, 250267.

Jeppesen, E., Jensen, J. P., Søndergaard, M., Lauridsen, T., \& Landkildehus, F. (2000). Trophic structure, species richness and biodiversity in danish lakes: Changes along a phosphorus gradient. Freshwater Biology, 45, 201213.

Kopacek, J., Brzakova, M., Hejzlar, J., Nedoma, J., Porcal, P., \& Vrba, J. (2004). Nutrient cycling in a strongly acidified mesotrophic lake. Limnology and Oceanography, 49, 12021213.

Marchant, R. (2002). Do rare species have any place in multivariate analysis for bioassessment? Journal of the American Benthological Society, 21, 311313.

McCullagh, P., \& Nelder, J. A. (1989). Generalized linear models. London, UK: Chapman \& Hall.

Metcalfe, J. L. (1989). Biological water quality assessment of running waters based on macroinvertebrate communities: History and present status in Europe. Environmental Pollution, 60, 101139.

Moons, K. G. M., Donders, A. R. T., Steyerberg, E. W., \& Harrell, F. E. (2004). Penalized maximum likelihood estimation to directly adjust diagnostic and prognostic prediction models for overoptimism: A clinical example. Journal of Clinical Epidemiology, 57, 12621270.

Moss, B. (1987). The art of lake restoration. New Scientist, 113,4143 .

Moss, B. (1988). Ecology of fresh waters: Man and medium (2nd ed.). Oxford: Blackwell Scientific.

Moss, B., Stephen, D., Alvarez, C., Bécares, E., Van de Bund, W., Van Donk, E., et al. (2003). The determination of ecological quality in shallow lakes a tested classification system (ECOFRAME) for implementation of the European water framework directive. Aquatic Conservation: Marine and Freshwater Ecosystems, 13, 507549.

Parsons, M., Thoms, M. C., \& Norris, R. H. (2004). Development of a standardised approach to river habitat assessment in Australia. Environmental Monitoring and Assessment, 98, 109130.
Reckhow, K. H., Black, R. W., \& Stockton, T. B. (1987). Empirical models of fish response to lake acidification. Canadian Journal of Fisheries and Aquatic Sciences, 44, 14321442.

Regan, T. J., Master, L. L., \& Hammerson, G. A. (2004). Capturing expert knowledge for threatened species assess ments: A case study using NatureServe conservation status ranks. Acta Oecologica, 26, 95107.

Reynoldson, T. B., Norris, R. H., Resh, V. H., Day, K. E., \& Rosenberg, D. M. (1997). The reference condition: A comparison of multimetric and multivariate approaches to assess water quality impairment using benthic macro invertebrates. Journal of the North American Benthological Society, 16, 833852.

Richardson, J. S., \& Healey, M. C. (1996). A healthy Fraser River? How will we know when we achieve this state? Journal of Aquatic Ecosystem Health, 5, 107115.

Rush, C., \& Roy, R. (2001). Expert judgement in cost estimating: Modelling the reasoning process. Concurrent Engineering: Research and Applications (CERA) Journal, 9, 271284.

Scheffer, M. (1998). Ecology of shallow lakes. London: Chapman \& Hall.

Scheffer, M., Hosper, S. H., Meijer, M. L., Moss, B., \& Jeppesen, E. (1993). Alternative equilibria in shallow lakes. Trends in Ecology \& Evolution, 8, 275279.

Schmidt, F. L. (1996). Statistical significance testing and cumulative knowledge in psychology: Implications for training of researchers. Psychological Methods, 1, 115129.

Søndergaard, M., Jeppesen, E., Jensen, J. P., \& Amsinck, S. L. (2005). Water framework directive: Ecological classifi cation of Danish lakes. Journal of Applied Ecology, 42, 616629.

Sullivan, T. J., Saunders, M. C., Tonnessen, K. A., Nash, B. L., \& Miller, B. J. (2005). Application of a regionalized knowledge based model for classifying the impacts of nitrogen, sulphur, and organic acids on lakewater chem istry. Knowledge Based Systems, 18, 5568.

Tonn, W. M., Paszkowski, C. A., Scrimgeour, G. J., Aku, P. K. M., Lange, M., Prepas, E. E., et al. (2003). Effects of forest harvesting and fire on fish assemblages in boreal plains lakes: A reference condition approach. Transactions of the American Fisheries Society, 132, 514523.

Trexler, J. C., \& Travis, J. (1993). Nontraditional regression analyses. Ecology, 74, 16291637.

Van Houwelingen, J. C., \& Le Cessie, S. (1990). Predictive values of statistical models. Statistics in Medicine, 9, 13031325.

Van Steen, J. F. J. (1992). A perspective on structured expert judgement. Journal of Hazardous Materials, 29, 365385. 